\title{
Mews at the time of ICU discharge is associated with outcome
}

\author{
IA Meynaar, , P Huber, AE van den Berg, J Vermeulen, K Toorenburg, P Melief, R Baak \\ From ESICM LIVES 2015 \\ Berlin, Germany. 3-7 October 2015
}

\section{Introduction}

The objective of this study was to see if the modified early warning score (MEWS) on discharge from the ICU to the ward is associated with outcome.

\section{Patients and Methods}

The study was done in the HagaZiekenhuis, a 600-bed teaching hospital in The Hague, Netherlands with all specialties available including cardiac surgery and neurosurgery. The hospital has a 16-bed adult ICU and an ICU based medical emergency team (MET). A MEWS is used throughout the hospital to monitor patients' vital signs and a score of 3 points or more is the threshold to alert the patients' doctor and the MET if necessary. As of 2013 the MEWS was to be recorded in the ICU discharge notes of all patients discharged from the ICU to the nursing wards of the hospital. For all consecutive patients admitted to the ICU in 2013 and discharged to the ward we collected baseline characteristics, outcome data and MEWS on discharge to study the association between outcome as measured by

(1) post-ICU hospital mortality,

(2) post ICU length-of-stay and

(3) ICU readmission rate.

\section{Results}

During the study period, 1297 individual patients were admitted to the ICU. One-hundred and fifty four patients died in the ICU, 75 patients were discharged towards home or another hospital and in 355 patients the MEWS was not recorded in the discharge notes, leaving us with a study population of 713 patients who were discharged from the ICU tot the ward with MEWS available.

Table 1. Basic characteristics

\begin{tabular}{lllll}
\hline & $\begin{array}{l}\text { All patients } \\
(\mathbf{n}=\mathbf{7 1 3})\end{array}$ & $\begin{array}{l}\text { MEWS on ICU discharge }<=\mathbf{2} \\
(\mathbf{n}=\mathbf{6 6 3})\end{array}$ & $\begin{array}{l}\text { MEWS on ICU discharge }>=\mathbf{3} \\
(\mathbf{n}=\mathbf{5 0})\end{array}$ & $\mathbf{P}$ \\
\hline Male & $497(69.7 \%)$ & $459(69.2 \%)$ & $38(76.0 \%)$ & $\mathrm{ns}(1)$ \\
\hline Age & $64.7(13.6)$ & $64.8(13.6)$ & $64.1(13.3)$ & $\mathrm{ns}(2)$ \\
\hline $\begin{array}{l}\text { Apache IV on ICU } \\
\text { admission }\end{array}$ & $59.0(25.1)$ & $57.7(24.5)$ & $75.9(26.8)$ & $<0.001(2)$ \\
\hline LOS ICU & & & $2.3(0.9-5.7)$ & $<0.001(3)$ \\
\hline
\end{tabular}

Table 2. Outcome data

\begin{tabular}{lllll}
\hline & All patients & MEWS on ICU discharge $<=\mathbf{2}$ & MEWS on ICU discharge $>=\mathbf{3}$ & $\mathbf{p}$ \\
\hline Hospital mortality & $33 / 733(4.6 \%)$ & $22 / 663(3.3 \%)$ & $11 / 50(22.0 \%)$ & $<0.001(1)$ \\
\hline LOS after ICU discharge (4) & $5.2(4.1-9.8)$ & $5.2(4.1-9.2)$ & $8.2(5.2-14.2)$ & $0.005(3)$ \\
\hline ICU readmission & $45 / 713(6.3 \%)$ & $37 / 626(5.6 \%)$ & $8 / 50(16.0 \%)$ & $0.01(1)$ \\
\hline
\end{tabular}

HagaZiekenhuis, ICU, The Hague, Netherlands

(c) 2015 Meynaar et al.; This is an Open Access article distributed under the terms of the Creative Commons Attribution License (http:// creativecommons.org/licenses/by/4.0), which permits unrestricted use, distribution, and reproduction in any medium, provided the original work is properly cited. 
(1) Chi square test

(2) t-Test

(3) Mann Whitney U test

(4) in hospital survivors $(n=680)$

\section{Conclusions}

In patients discharged from the ICU to the ward, a high MEWS at the time of ICU discharge is associated with a significantly higher post-ICU mortality rate, a significantly higher ICU readmission rate and, in hospital survivors, a significantly increased hospital length-of -stay (LOS) after ICU discharge.

Published: 1 October 2015

doi:10.1186/2197-425X-3-S1-A136

Cite this article as: Meynaar et al:: Mews at the time of ICU discharge is associated with outcome. Intensive Care Medicine Experimental 2015 3(Suppl 1):A136.

\section{Submit your manuscript to a SpringerOpen ${ }^{\mathcal{O}}$ journal and benefit from:}

- Convenient online submission

- Rigorous peer review

- Immediate publication on acceptance

- Open access: articles freely available online

- High visibility within the field

- Retaining the copyright to your article

Submit your next manuscript at $>$ springeropen.com 